Dedi Robani ${ }^{1}$

Nevi Yarni ${ }^{2}$

\section{HUBUNGAN PERSEPSI BELAJAR DENGAN MOTIVASI BELAJAR PRAJA IPDN KAMPUS SUMATERA BARAT}

\begin{abstract}
Abstrak
Penelitian ini bertujuan untuk menganalisis hubungan kepribadian dalam hal motivasi berprestasi dan persepsi belajar praja IPDN Kampus Sumatera Barat dan mengevaluasi keberhasilan system Tritunggal terpusat, yaitu pengajaran, pelatihan, dan pengasushan dalam mengembangakan kepribadian Praja. Jenis penelitian ini adalah penelitian kuantitatif dengan menggunakan data angket persepsi dan angket motivasi dengan populasi penelitian praja Institut Pemerintahan Dalam Negeri (IPDN) Kampus Sumatera Barat. Populasi Penelitian ini Praja IPDN Kampus Sumatra Barat yang berjumlah 400 orang. Sampel penelitian ini adalah 30 orang Madya Praja tingkat II berjumlah 60.Berdasarkan hasil deskripsi data dan analisis hipotesis, maka diketahui bahwa: terdapat hubungan persepsi dengan motivasi belajar praja IPDN dapat diperoleh kesimpulan bahwa terdapat hubungan perspsi dengan motivasi belajar parja IPDN kampus Sumatera Barat yang dengan perolehan koefisien korelasi sebesar 0,857 dengan kategori sangat tinggi. Dapat disimpulkan bahwa perspsi siswa akan pentingnya belajar juga memiliki peranan dalam tingginya motivasi siswa dalam belajar.
\end{abstract}

Kata Kunci: Motivasi, Prestasi, Persepsi Belajar, IPDN

This study aims to analyze the relationship between personality in terms of achievement motivation and perceptions of IPDN praja learning in the West Sumatra Campus and evaluate the success of the centralized Trinity system, namely teaching, training, and excellence in developing Praja's personality. This type of research is quantitative research using questionnaire data on perception and motivation questionnaires with the population of the praja research population Institute of Domestic Administration (IPDN), West Sumatra Campus. The population of this study was Praja IPDN of West Sumatra Campus, amounting to 400 people. The sample of this study was 30 Madya Praja level II totaling 60. Based on the results of data description and analysis of hypotheses, it is known that: there is a correlation between perception and motivation of IPDN praja learning can be concluded that there is a perspective relationship with the motivation to study IPDN in West Sumatra campus with acquisition correlation coefficient of 0.857 with a very high category. It can be concluded that students' perspectives on the importance of learning also have a role in the high motivation of students in learning.

Keywords: Motivation, Achievement, Learning Perception, IPDN

\footnotetext{
${ }^{1}$ Mahasiswa Prodi Ilmu Pendidikan, Universitas Negeri Padang Alamat email dederobandi@ gmail.com

${ }^{2}$ Dosen/Staf Pengajar Prodi Ilmu Pendidikan, Universitas Negeri Padang
} 


\section{PENDAHULUAN}

Institut Pemerintahan Dalam Negeri (IPDN) merupakan sebuah lembga pendidikan kedinasan yang di kelola oleh Kementrian Dalam Negeri dan Otonomi Daerah yang bertujuan untuk menghasilkan Pamong Praja yang memiliki kulitas unggul, memiliki kompetensi dan jati diri kepamongprajaan, serta dapat mengembangkan kreativitas, inovasi, dan menguasai ilmu pengetahuan dan teknologi yang berguna untuk meningkatkan kinerja hingga dapat menghadapi tantangan dan peluan di era revolusi industri 4.0 yang menuntut aparatur pemerintahan yang profesional serta mampu mewujudkan Good Governance.

Keberadaan kader pemerintahan sebagai pamong dan pelayan masyarakat menjadi sangat penting dan strategis, hal ini sejalan dengan perubahan paradigm di bidang pemerintahan yang mengakibatkan perubahan mendasar bagi penyelenggaraan pemerintahan dimasa yang akan datang. Oleh karena itu aparatur pemerintahan dituntut untuk responsive, proaktif dan berorientasi kepada pelayanan masyarakat (public service) menuju terwujudnya kesejahteraan masyarakat. Upaya meningkatkan kualitas dan profesionalisme aparatur atau pamong praja dimulai dengan mengembalikan citra Pamong Praja itu sendiri, yang telah dilakukan secara sistematis sejak didirikannya lembaga pendidikan kepamongprajaan, yaitu mulai dari OSVIA, MOSVIA, KDC, APDN hampir di setiap propinsi, kemudian diintegrasikan menjadi STPDN (Sekolah Tinggi Pemerintahan Dalam Negeri) dan IIP (Institut Pemerintahan Dalam Negeri), sehingga terbit Keputusan Presiden Nomor 87 Tahun 2004 tentang Penggabungan Sekolah Tinggi Pemerintahan Dalam Negeri ke dalam Institut Ilmu Pemerintahan, dan kemudian namanya diubah menjadi Institut Pemerintahan Dalam Negeri (IPDN).

Kepamongprajaan merupakan suatu istilah yang akrab di lingkungan Kementerian Dalam Negeri, karena IPDN umumnya dikenal sebagai perguruan tinggi dengan sebutan pendidikan tinggi kedinasan dalam naungan Kementerian Dalam Negeri. Menurut Hamdi (2011), belum ada penanda khusus dari keberadaan kedua perguruan tinggi tersebut berkaitan dengan istilah pamong praja, kecuali sebutan sebagai tempat penggemblengan (kawah candradimuka) kader pemerintahan dalam negeri.

Terwujudnya kondisi aparatur pemerintahan yang sedemikian rupa, diawali dari pembentukan kader pemerintahan yang komperehensif melalui pendidikan kedinasan. Integrasi antara Institut Ilmu Pemerintahan (IIP) dan Sekolah Tinggi Pemerintahan Dalam Negeri (STPDN) menjadi Institut Pemerintahan Dalam Negeri (IPDN) merupakan sarana untuk menghasilkan kader pemerintahan yang profesional.

Sistem pendidikan seperti Institut Pemerintahan Dalam Negeri (IPDN) yang menganut sistem Tritunggal Terpusat yaitu Pengajaran, Pelatihan, dan Pengasuhan (JARLATSUH) akan mempengaruhi pola hubungan antarvariabel yang terkait dengan kepribadian praja. Oleh karena itu, studi mengenai hubungan antara motivasi berprestasi dan persepsi belajar praja IPDN merupakan permasalahan yang menarik untuk dikaji.

Tujuan penelitian ini adalah: 1) memperoleh informasi tentang pola hubungan kepribadian dalam hal ini motivasi berprestasi dan persepsi belajar praja IPDN 2) mengevaluasi keberhasilan sistem Tritunggal Terpusat yaitu Pengajaran, Pelatihan, dan Pengasuhan (JARLATSUH) dalam mengembangkan kepribadian praja

\section{METODE}

Jenis penelitian yang digunakan adalah penelitian korelasional, yaitu salah satu jenis penelitian yang dirancang untuk menentukan tingkat hubungan antar variabel-variabel yang berbeda dalam suatu populasi. Populasi yang diambil dalam penelitian ini praja Institut Pemerintahan Dalam Negeri (IPDN) Kampus Sumatera Barat. Pengambilan sampel yang digunakan adalah teknik proporsional random sampling, dimana untuk setiap tingkat diambil secara acak dengan proporsi $50 \%$.

Instrumen yang digunakan untuk mengumpulkan data dalam penelitian ini, yaitu instrumen non tes (Kuesioner). Kuesioner digunakan untuk mendapatkan data motivasi belajar. Data hasil belajar didapat dari IPDN. Langkah-langkah pelaksanaan pengumpulan data dari ketiga variabel yang diteliti adalah melakukan persiapan dan pelaksanaan di lapangan. Langkah 
persiapan adalah tahap mempersiapkan instrumen, melakukan konsultasi dengan berbagai pihak yang terkait. Selanjutnya melakukan penentuan waktu penelitian dan membahas hal-hal teknis yang diperlukan. Setelah langkah persiapan ini selesai, dilanjutkan dengan pelaksanaan penelitian di lapangan (Zagoto, 2019).

Pada tahap ini peneliti menyebarkan instrumen kepada responden. Teknik analisa data pada penelitian ini menggunakan analisis deskriptif yang dikemukakan Sudjana dan Ibrahim, 2007 yaitu

a. Persentase

$$
\begin{aligned}
& \qquad P=\frac{f}{n} x 100 \% \\
& \begin{array}{l}
\mathrm{P}=\text { persentase } \\
\mathrm{f}=\text { frekuensi } \\
\mathrm{n}=\text { Sampel }
\end{array} \\
& \bar{X}=\frac{\mathrm{FX}}{\mathrm{n}} \\
& \text { Keterangan: } \\
& \begin{array}{l}
\mathrm{X} \quad: \text { Mean } \\
\mathrm{FX} \quad: \text { Jumlah data } \\
\quad: \text { Sampel }
\end{array} \\
& \quad S D=\sqrt[i]{\frac{\sum_{F d^{2}}}{n}-\frac{\sum_{F d^{2}}}{n}}
\end{aligned}
$$

b.

Keterangan:

$$
\begin{aligned}
& \mathrm{SD}=\text { Standar deviasi } \\
& \mathrm{I} \quad=\text { Interval } \\
& \mathrm{Fd} \quad=\text { Frekuensi distribusi }
\end{aligned}
$$

Syarat uji :

a. Uji Normalitas

Uji Normalitas data digunakan untuk mengetahui apakah populasi data berdistribusi nornal atau tidak. Normalitas data diuji dengan uji Liliefor dengan melihat nilai pada Kolmogorov Smirnov melalui analisa SPSS versi 15. Data dinyatakan berdistribusi normal jika signifikansi lebih besar dari 0,05. (Priyatno, 2010: 71)

\section{b. Uji Linieritas}

Uji linieritas dilakikan dengan uji $\mathrm{F}$, yang bertujuan untuk melihat apakah data populasi yang diperoleh linier/tidak. Pedoman dalam pengambilan keputusan dengan menggunakan uji $\mathrm{F}$ adalah, jika nilai signifikansi atau nilai porobabilitas $(\mathrm{p})<0,05$, data yang digunakan linier, sementara jika nilai nignifikansi atau nilai probabilitas $(p)>0,05$ data yang digunakan tidak linier.

Pengujian hipotesis sebagai berikut:

1. Analisis regresi ( $\mathrm{r} 2)$

Regresi sederhana dapat dianalisis karena didasari oleh hubungan fungsional atau hubungan sebab akibat (kausal) variabel $\mathrm{X}$ terhadap variabel $\mathrm{Y}$ dengan rumus sebagai berikut:

$$
\mathrm{y}=\mathrm{a}+\mathrm{bX}
$$

\section{Uji Korelasi (Pearson Product Moment) \\ Rumusnya sebagai berikut:}


Keterangan:

$$
r_{x y}=\frac{N \sum X Y-\left(\sum X\right)(\Sigma Y)}{\sqrt{\left.\left\{N \Sigma X^{2}-(\Sigma X)^{2}\right\}\left\{N \Sigma Y^{2}-(\mathbf{Y})^{2}\right)\right\}}}
$$

$\mathrm{rxy}=$ koofesien korelasi yang

dicari

$\mathrm{N}$ = banyak subjek pemilik nilai

$\mathrm{X}=$ nilai variabel $\mathrm{X} 1$

Y= nilai variabel Y (Suharsimi, 2006:146)

Pedoman untuk memberikan interpretasi koofisien korelasi sebagai berikut:

$\begin{array}{ll}0,0-0,199 & \text { sangat rendah } \\ 0,2-0,399 & \text { rendah } \\ 0,4-0,599 & \text { sedang } \\ 0,6-0,799 & \text { kuat } \\ 0,8-1,00 & \text { sangat kuat }\end{array}$

\section{HASIL DAN PEMBAHASAN}

Hipotesis dalam penelitian ini adalah: "terdapat hubungan yang antara motivasi belajar dengan hasil belajar Praja IPDN Kampus Sumatera Barat.

Pengujian hipotesisnya adalah sebagai berikut:

$\mathrm{Ho}=$ Tidak terdapat hubungan yang antara motivasi belajar dengan hasil belajar praja IPDN Kampus Sumatera Barat.

$\mathrm{H} 1=$ Terdapat hubungan yang antara motivasi belajar dengan hasil belajar praja IPDN Kampus Sumatera Barat.

Hasil analisis hubungan motivasi belajar dengan hasil belajar praja IPDN Kampus Sumatera Barat seperti tabel berikut ini :

Tabel Analisis Regresi Sederhana Antara Variabel Motivasi Belajar dengan Hasil belajar Praja IPDN Kampus Sumatera Barat.

\begin{tabular}{|c|c|c|c|c|c|c|}
\hline \multirow{2}{*}{ Variabel } & \multirow{2}{*}{$\begin{array}{r}\text { Koefisien } \\
\text { Regresi }\end{array}$} & \multirow{2}{*}{$\begin{array}{c}\text { Standar } \\
\text { Eror }\end{array}$} & \multicolumn{2}{|r|}{$\mathrm{T}$} & \multicolumn{2}{|c|}{$\begin{array}{c}\text { Pengujian } \\
\text { Hipotesis }\end{array}$} \\
\hline & & & Hitung & Tabel $\alpha=0,05$ & Ho & $\mathrm{H} 1$ \\
\hline $\mathrm{X} 2$ & 0,125 & 0,040 & 3,160 & 1,664 & & $\sqrt{ }$ \\
\hline $\begin{array}{l}\text { Constanta } \\
\text { StandarEr } \\
\text { r.square } \\
\text { r }\end{array}$ & ofEast $=$ & & & & & \\
\hline
\end{tabular}

Sumber : Pengolahan Data Primer, 2019

Berdasarkan analisis regresi linier sederhana dari data penelitian diperoleh koefisien regresi 0,125 dan konstanta 66,958 . Bentuk hubungan dapat disajikan dalam persamaan regresi $Y=66,958+0,125 \mathrm{X} 2$, hasil pengujian melalui uji t diperoleh thitung sebesar 3,160,

sedangkan t tabel pada taraf kepercayaan $\alpha=0,05$ sebesar 1,664 , kekuatan hubungan sebesar 
0,416, yang berarti memiliki kekuatan sedang. Pengaruh motivasi terhadap hasil belajar adalah sebesar $11,2 \%$. Dengan demikian terbukti bahwa terdapat hubungan antara motivasi dengan hasil belajar atau hipotesis yang diajukan diterima. Selanjutnya di uji menggunakan uji $\mathrm{F}$ adapun hasilnya dapat dilihat pada tabel berikut ini :

I. TABEL ANALISIS VARIANS VARIABEL MOTIV ASI DENGAN HASIL BELAJAR PRAJA IPDN KAMPUS SUMATERA BARAT

\begin{tabular}{|l|l|c|c|c|c|c|}
\hline \multirow{2}{*}{ Source } & \multirow{2}{*}{$\begin{array}{c}\text { Sum Of } \\
\text { Square }\end{array}$} & \multirow{2}{*}{ DF } & \multirow{2}{*}{$\begin{array}{c}\text { Mean } \\
\text { Square }\end{array}$} & \multirow{2}{*}{ Fo } & \multicolumn{2}{|c|}{ F tabel } \\
\cline { 6 - 8 } & & & & $\alpha 0,05$ & $\alpha 0,01$ \\
\hline Regression & 301,686 & 1 & 301,686 & 9,988 & 3,95 & 6,90 \\
Residual & 2386,191 & 79 & 30,205 & & & \\
\hline Total & 268,877 & 80 & & & & \\
\hline
\end{tabular}

Sumber : Pengolahan Data Primer, 2019

Berdasarkan Tabel di atas diperoleh harga $\mathrm{F}$ hitung sebesar 9,988, harga ini lebih besar dibandingkan dengan harga $\mathrm{F}$ tabel dengan $\mathrm{DF}$ pembilang 1 dan penyebut 79 pada taraf kepercayaan $\alpha=0,05$ sebesar 3,95 dan $\alpha=0,01$ sebesar 6,90 dengan membandingkan $F$ hitung dengan $\mathrm{F}$ tabel tersebut diketahui bahwa koefisien regresi signifikan karena $\mathrm{F}$ hitung lebih besar dari F tabel.

II. TABEL KEBERARTIAN ANALISIS KOEFISIEN RELASI RXY

\begin{tabular}{|l|c|c|}
\hline \multirow{2}{*}{$\mathrm{R} \times 2 \mathrm{y}$} & \multicolumn{2}{|c|}{$\mathrm{r}$ tabel pada taraf signifikan } \\
\cline { 2 - 3 } & $\alpha 0,05$ & $\alpha 0,01$ \\
\hline 0,335 & 0,176 & 0,244 \\
\hline
\end{tabular}

Sumber : Pengolahan Data Primer, 2019

Hasil perhitungan koefisien korelasi antara variabel motivasi dengan hasil belajar praja IPDN Kampus Sumatera Barat rxy sebesar 0,816. Hasil pengujian menunjukan terdapat hubungan antara motivasi dengan hasil belajar praja IPDN Kampus Sumatera Barat, melalui

model regresi $66,958+0,125 \mathrm{X} 2$.

Model persamaan regresi motivasi belajar (X2) dengan hasil belajar (Y) memperlihatkan bahwa garis linier bergerak dari titik 76,1969 sampai titik 87,8083. Model ini juga menunjukkan bahwa persebaran data penelitian motivasi belajar dengan hasil belajar mendekati garis linier. Jadi dapat disimpulkan bahwa model persamaan regresi ini adalah signifikan dan linier. Motivasi sebagian besar Praja IPDN Kampus Sumatera Barat Tingakat III umumnya tinggi $(39,5 \%)$. Hasil penelitian menunjukkan terdapat hubungan antara motivasi dengan hasil belajar Praja IPDN. Hubungan ini dilihat dari t hitung $>t$ tabel $(3,60>1,664)$ yang berarti semakin tinggi motivasi belajar semakin hasil belajar. Koofisien korelasi (r) yaitu sebesar 0,857 dan besarnya koofisien determinasi ( $\mathrm{r} 2$ ) sebesar 0,112 , hal ini berarti bahwa motivasi belajar berkontribusi sebesar $11,2 \%$ terhadap hasil belajar.

Sardiman (2011:75) menyatakan motivasi belajar merupakan salah satu faktor yang menentukan keefektifan pembelajaran. Dalam kegiatan belajar, motivasi dapat dikatakan sebagai keseluruhan daya penggerak didalam diri siswa yang menimbulkan kegiatan belajar, yang menjamin kelangsungan dari kegiatan belajar, dan yang memberikan arah pada kegiatan belajar, sehingga tujuan yang dikehendaki oleh subjek belajar itu dapat tercapai. Siswa yang memiliki motivasi yang kuat, akan mempunyai banyak energi untuk kegiatan belajar. Selanjutnya Uno (2012) menyatakan motivasi motivasi dalam belajar yaitu: (a) menentukan hal-hal yang dapat dijadikan penguat belajar, (b) memperjelas tujuan belajar yang hendak dicapai, (c) menentukan ragam kendali terhadap rangsangan belajar, (d) menentukan ketekunan belajar (Zagoto, dkk., 2018; Dakhi, O. (2013; Sarumaha, 2018). 


\section{SIMPULAN}

Motivasi sebagian besar Praja IPDN Kampus Sumatera Barat umumnya baik (39,5\%). Hasil penelitian ini menunjukkan terdapat hubungan antara motivasi dengan hasil belajar Praja IPDN Kampus Sumatera Barat, kekuatan hubungan antara motivasi dengan hasil belajar termasuk sedang dan kontribusi yang termasuk kecil, koofisien korelasi (r) yaitu sebesar 0,857 dan besarnya koofisien determinasi (r2) sebesar 0,112 , hal ini berarti bahwa motivasi belajar berkontribusi sebesar $11,2 \%$ terhadap hasil belajar.

\section{SARAN}

Berdasarkan hasil penelitian yang dilaksanakan di Kampsus IPDN Provinsi Suatera Barat disarankan kepada pihak Kampsu IPDN Sumatera Barat serta kepada Praja agar terus meingkatkan prestasi dan motivasi belajar seperti yang tertuang pada PEDUPRA (Oeraturan Kehidupan Praja) atau yang telah ditetapkan pemerintah supaya prestasi bisa tetap terjaga sehingga terciptanya Praja yang bekulitas unggul untuk mewujudkan Good Governnace.

\section{DAFTAR PUSTAKA}

Dakhi, O. "Aplikasi Pendeteksian Kerusakan File Akibat Virus Dengan Menggunakan Metode Heuristic.” Pelita Informatika Budi Darma, vol. 4, no. 1, pp. 35-41, 2013.

Dakhi, O. 2013. Belajar Javascript Dengan Mudah Dan Detail. Jakarta: Dapur Buku. pp. 1-202.

Dewey, John. 2002. Pengalaman dan Pendidikan. Terjemahan John De Santo. Yogyakarta: Kepel Press.

Frederick, J. Mc. Donald. 1959. Educational Psycholoy. Tokyo: Overseas Publication LTD. Hamalik, Oemar. 2000. Psikologi Belajar Mengajar: Jakarta: Sinar Baru Algesindo Sardiman.

2011. Interaksi dan Motivasi Belajar Mengajar. Jakarta: PT Raja Grafindo Persada.

http://ainamulyana.blogspot.co.id/2012/02/motivasi-belajar.html http://journal.uny.ac.id/index.php/jpv/article/viewFile/8118/6872

Peraturan Pemerintah Nomor 30 Tahun 1980 tentang Peraturan Disiplin Pegawai Negeri Sipil.

Sarumaha, R., Harefa, D., \& Zagoto, Maria M. (2018). Upaya Meningkatkan Kemampuan Pemahaman Konsep Geometri Transformasi Refleksi Siswa Kelas XII-IPA-B SMA Kampus Telukdalam Melalui Model Pembelajaran Discovery Learning Berbantuan Media Kertas Milimeter. Jurnal Education and development, Vol.6 No.1, 90-96. https://doi.org/10.37081/ed.v6i1.668

Suharsimi. 2006. Prosedur Penelitian .Jakarta : Rineka Cipta.

Zagoto, Maria M., Yarni, Nevi; Dakhi, O. (2019). Perbedaan Individu dari Gaya Belajarnya Serta Implikasinya Dalam Pembelajaran. Jurnal Review Pendidikan dan Pengajaran, 2(2), 259265.

Zagoto, Maria M. \& Dakhi, O (2018). Pengembangan Perangkat Pembelajaran Matematika Peminatan Berbasis Pendekatan Saintifik Untuk Siswa Kelas XI Sekolah Menengah Atas. Jurnal Review Pendidikan dan Pengajaran, 1(1), 157-170.

Zagoto, Maria M. (2018). Pengembangan Perangkat Pembelajaran Matematika Berbasis Realistic Mathematic Educations Untuk Siswa Kelas V Sekolah Dasar, Jurnal Education And Development, vol. 3, no. 1, p. 53, Feb. 2018. https://doi.org/10.37081/ed.v3i1.139 